\title{
GENETIC ANALYSIS AND HETEROSIS FOR SOME QUANTITATIVE TRAITS IN TOMATO (SOLANUM LYCOPERSICUM L.)
}

\author{
Mona R. Khalil(1) and M. I. Mahmoud(2) \\ (1) Horticulture Dept., Fac. Agric. Menoufia Univ., Shebin El-Kom, Egypt. \\ (2) Plant prod. Dep. (vegetable) Fac. Environ. Agric. Sci., Arish Univ., Egypt. \\ Received: Jun. 18, 2019
}

Accepted: Jul. 1, 2019

\begin{abstract}
This study was conducted during three successive early summer seasons of 2016- 2018 at the experimental farm of both faculty of Agricultural, Menoufia University, Shebin El-Kom and Bahga Agricultural development company, Anshas, sharkia. The present investigation was aimed to obtain more information on combining ability and degree of heterosis for some plant and fruit characters. Four breeding lines and one cultivar of tomato (Solanum lycopersicum L.) and their ten $F_{1}$ 's resulted from a half - diallel cross were evaluated and the component of genetic variance, combining ability and the extent of heterosis were determined for some tomato traits, i.e., number of primary branches and leaves, early and total yield, average fruit weight and fruit firmness. The analysis of variance reflected significant differences among the studied genotypes for all the traits studied. Estimation of the magnitude of variance due to general and specific combining ability effects ( $\sigma^{2}$ GCA \& $\sigma^{2}$ SCA) showed that both additive and non-additive gene effects were significant and important in inheritance of all studied traits, except average fruit weight. However, the estimated genetic parameters revealed that the additive gene effects were more important and play the main role in the inheritance of early and total yield, average fruit weight and fruit firmness and could be improved by varietal breeding program. While, the non-additive genetic variance was found predominance for number of branches and leaves and improving these two traits could be occurred by heterosis breeding. The two lines MON-8 and MON-9 were considered as the best general combiner parents, since they recorded positive GCA effects for four traits. The cross combinations MON-8 $\times$ MON-9 and MON-9 x MON-15 were the best specific combinations, since they recorded significant SCA values for five and four traits. Relative heterosis (MPH\%) was observed for all studied traits, except, average fruit weight, while heterobeltiosis (BPH\%) was observed in some crosses for number of branches and leaves as well as early and total yield. Based on the standard heterosis (SH \%) expressed by the hybrids MON-8 X MON-9 and MON-9 X MON-15 were found to be superior since significantly exceeded the commercial hybrid (control).
\end{abstract}

Key words: General and specific combining ability, tomato, heterosis, degree of dominance, relative heterosis and heterobeltiosis.

\section{INTRODUCTION}

Recently the use of hybrid cultivars has increased dramatically that in all countries, since hybrid seeds are superior to open- pollinated varieties for earliness, yield, fruit quality and other important attributes. The breeders goal is to develop new hybrids characterized by high yield with good traits continually. This work required three important stages; production of new promising lines, determining the combining ability of these lines to chose the superior parents, and lastly production of the hybrid seeds in bulk of the promising $F_{1}$ hybrids. Also the choice of breeding 
method would be largely guided by the nature of gene action and the relatively magnitude of additive and non- additive variance in a breeding populations.

Combining ability has a prime importance in plant breeding since it provides information for the selection of parents and regarding the nature and magnitude of involved gene action. General combining ability (GCA) is owing to the activity of genes which are largely additive in their effects as well as additive $x$ additive interactions. While, specific combining ability (SCA) is regarded as an indication of loci with dominance variance (non-additive effects) and epestatic gene action. Diallel cross (half or complete) has appeared to be good one of the most appropriate approaches in preliminary screening the materials for GCA and SCA. High values for both GCA and SCA (additive and nonadditive) variances with the prevalence of additive effects $\left(\sigma^{2} A l \sigma^{2} D>1\right)$ were observed by several investigators for tomato. Among them, Aboshama et al. (2015) for number of branches per plant; Kansouh (2013a) and Enang et al . (2015) for number of leaves per plant; Ramadan et al. (2014) and Aboshama et al. (2015) for early yield ; Farzane et al. (2012) and Mahmoud and El-Eslamboly (2014) for total yield. Respecting the order, Kansouh (2013a), Savale et. al. (2017) and Al-Daej (2018) for average fruit weight; Khansouh (2013a) and Al-Daej (2018) for fruit firmness reported the preponderance of additive gene action in these traits.

On the other hand, other authors reported the predominance of nonadditive gene action in the inheritance of the same traits in other genotypes of tomato. Among them were Kansouh and Zakher (2011) and Babu et al. (2018) for number of branches; Kansouh and Zakher (2011) and Aminu and Mala (2015) for number of leaves; Kansouh and
Zakher (2011) and Kumari and Srivastava (2017) for early yield; Shende et al. (2012) and Ramana et al. (2017) for both total yield and average fruit weight. Also, the studies of Rakesh (2016) reported the prevalence of a non-additive gene action in the inheritance of fruit firmness in tomato.

Heterosis for yield, its components and fruit quality traits were extensively studied in tomato. In this respect, heterosis over the better parent as heterobeltiosis (BPH\%) was reported by yadav et al. (2013) and Sahu et al. (2016) for number of primary branches per plant; Kansouh and Masoud (2007) and Kansouh (2013b) for number of leaves ; Khalil (2009) and Jaiprakash Narayan et al. (2018) for early and total yield . Regarding average fruit weight, Shende et al. (2012) and Masry (2014) found BPH\% (heterobeltiosis). Meanwhile, most investigators such as Kansouh (2013 b) and AL-Daej (2018) reported nodominance for average fruit weight since the studied hybrids reflected intermediate values. The same trend was observed for fruit firmness by Kansouh (2013 b), and AL-Daej (2018), since most studied crosses showed intermediate values between their parents (nodominance) and some crosses reflected partial dominance towards the highest fruit firmness.

However, In many cases, the better parent of hybrid may be inferior to the best commercial check cultivar. Therefore, it will be desirable to estimate hybrid vigour (heterosis) in relation to the used commercial check cultivar. The superiority of F1 over the commercial check is known as useful I standard I economic heterosis. Respecting the order, Kansouh (2013b), Savale et al. (2017) and Jaiprakash Narayan et al. (2018) for number of branches and early and total yield; Kansouh and Masoud (2007) and Kansouh (2013b) for both fruit 
weight and firmness recorded significant commercial (standard) heterosis in tomato for the previous mentioned traits.

Keeping these points in mind, the present investigation was planned to obtain more information on combining ability and gene action to identify some lines I cultivars having good combining effect for some plant and fruit characters. Also, to determine the heterosis degree to determine some promising local tomato F1 hybrids suitable to Egypt conditions.

\section{MATERIALS AND METHODS}

The present study was carried out during three successive early summer seasons of 2016 - 2018. Four new breeding lines of tomato (Solanum lycopersicum L.), which were developed by Mona, R Khalil, i.e., MON-5, MON-8, MON-9 and MON-15 as well as, the cultivar Endless Summer were used in this study. In the season 2016 a $5 \times 5$ without reciprocals was made to obtain $10 F_{1}$ hybrids at the experimental farm, Faculty of Agriculture, Minoufia university, Shibin EL-Kom. The obtained $F_{1}$ crosses and their parents, in addition to the commercial hybrid Alissa $F_{1}$ (as control) were evaluated in the two successive early summer seasons of 2017 and 2018 at the experimental farm of Bahga Agricultural development company, Anshas, Sharkia governorate. The seedlings were transplanted on February $15^{\text {th }}$ in a randomized complete blocks design with three replicates. Drip irrigation system was used and each plot consisted of three rows, $1.50 \mathrm{~m}$ width and $10 \mathrm{~m}$ length $\left(45 \mathrm{~m}^{2}\right)$, each row had one dripper line and the plants were spaced at $50 \mathrm{~cm}$. apart (60 plants I plot). Routine cultural practices, similar to those used in tomato commercial production were done as needed.
Data for number of primary branches and leaves per plant, were recorded at the end of the flowering stage on ten guarded plants per plot; early yield (ton I fed.) as the yield of the first three harvests, total yield (ton $I$ fed.) as the total weight of all harvested fruits (early and total yield were recorded firstly as $\mathbf{k g}$ $I$ plot and ton I fed. was calculated); average fruit weight (gm.) by dividing the total fruit weight by total fruit number ; fruit firmness $(\mathrm{g} / \mathrm{cm} 2)$ was measured by using a needle type pocket penetrometer. Data were recorded during the two seasons (2017 and 2018), then the combined data over the two seasons were done whenever the homogeneity of variances was detected. Analysis of variance, combining ability analysis, component of genetic variance (additive, $\sigma^{2} A$, and non-additive, $\sigma^{2} D$ ) were done as reported by Griffing (1956) method II, model I and Singh and Chaudhary (1995). Degree of dominance $\left(2 \sigma^{2} D / \sigma^{2} A\right)^{0.5}$ was made according to Kearsey and Pooni (1996). Average degree of heterosis (ADH $\%)$ was calculated over mid-parents (MPH $\%)$ and better parent (BPH \%) according to Mather and Jinks (1971). Heterosis also was calculated as standard heterosis (SH \%) based on commercial I standard hybrid as follow :

$\mathrm{SH} \%=\frac{\overline{\mathrm{F}_{1}}-\overline{\mathrm{CH}}}{\overline{\mathrm{CH}}} \times 100$

Where :

$$
\begin{array}{r}
\overline{\mathrm{F}_{1}} \text {, and } \overline{\mathrm{CH}}=\quad \text { The means of } \mathrm{F}_{1} \\
\text { generation, and commercial } \\
\text { hybrid (control), respectively. }
\end{array}
$$

Heterosis over the better parent (BPH $\%)$ was only calculated for the crosses that showed significant positive MPH\% values. Type of dominance (no, partial, complete and over) was obtained according to the dominance line (Kansouh, 2014) . 


\section{RESULTS AND DISCUSSION}

\section{A. Mean performances of the F1 hybrids and their parents:}

Highly significant differences among the parental genotypes and the crosses were detected for all studied traits (Table 1). For number of primary branches per plant, the parental genotypes values ranged from 4.61 (Endless Summer) to 6.68 branchs $I$ plant (line MON-9). Meanwhile, a range from 5.53 (cross MON-15 $x$ Endless Summer) to 8.16 branchs/plant (cross MON-8 x MON-9) was detected by the crosses. The overall mean value of the hybrids $\mathbf{6 . 8 9}$ branchs/plant) exceeded that of the parental genotypes (5.69 branchs / plant) by $21.09 \%$ indicating that, the resulted $F_{1}$ hybrids gave higher number than those of their parents. Compared with the commercial $F_{1}$ hybrid Alissa (control), the two hybrids MON-8 $x$ MON-9 and MON-9 $\times$ MON-15 were similar to the control in this respect. The same trend was observed for number of leaves per plant, since the same two lines and hybrids, i.e. , MON-8 , MON-9, MON-8 x MON-9 and MON-9 $x$ MON-15 recorded the highest number of leaves ( 70.83 , $75.27,93.02$ and 88.39 , respectively ). The overall mean value of the crosses (73.82) significantly exceeded that of the parental genotypes (61.36) by $20.32 \%$. Also, insignificant differences were detected between the two crosses MON-8 $x$ MON-9 and MON-9 x MON-15 (the highest number of leaves) and the control (Alissa F1).

For early yield, the parental genotypes and their crosses varied widely in this respect. The parents produced early yield mean values ranged from 2.247 (cv. Endless Summer) to 8.120 ton/ fed. (line MON-9) with an overall mean value of 5.23 ton/fed., while for $F_{1}$ hybrids, they ranged from 3.778 (cross MON-8 $x$
Endless Summer) to 10.103 (cross MON-5 $x$ MON-9) with a general value of 6.07 ton/fed. , which significantly exceeded the parental genotypes by overall mean value of $16.06 \%$. However, the cross MON-5 x MON-9 was considered the best hybrid which showed the highest early yield (10.103 ton $I$ fed.) among the resulted $F_{1}$ hybrids and significantly exceeded the commercial hybrid $F_{1}$ Alissa (control) by $24.39 \%$. Regarding total yield (Table 1), the parental genotypes and their hybrids varied widely in this respect. The total yield values ranged from 13.250 (Endless Summer) to 21.648 (line MON-8) in the parents with an overall mean of 17.794 ton/fed., while for $F_{1}$ 's the range was from 15.198 (cross MON-15 $x$ Endless Summer) to 25.508 (cross MON-9 $x$ MON15) with a general value of 19.199 ton/fed. The two crosses MON-8 $\times$ MON-9 and MON-9 x MON-15 performed significant better total yield $(24.827$ and 25.508 ton/fed.) than those of the parents and the other hybrids showed insignificant differences compared with the control (Alissa $F_{1}$ hybrid) .

Average fruit weight reflected also a great variation among the studied genotypes (Table 1). The fruits recorded average fruit weight ranged from 91.64 (line MON-9) to 170.42 ( line MON-5) with an overall mean of $132.96 \mathrm{gm}$., while the tested $F_{1}$ crosses ranged from 110.46 (cross MON-9 $x$ Endless Summer) to 152.72 (cross MON-5 x MON-15) with a general mean of $134.06 \mathrm{gm}$. Regarding fruit firmness, the line MON-15 produced the firmest fruits $\left(648.33 \mathrm{gm} / \mathrm{cm}^{2}\right.$.), followed by the line MON-8 with a value of $621.67 \mathrm{gm} / \mathrm{cm}^{2}$. Among the studied crosses, MON-8 x MON-15 followed by MON-15 $x$ Endless Summer recorded the firmest values (631.67 and 621.67 $\mathrm{gm} / \mathrm{cm}^{2}$., respectively). 
Genetic analysis and heterosis for some quantitative traits in tomato

Table (1): Mean performances of the evaluated F1 hybrids and their parents for some plant and fruit characteristics based on combined analysis.

\begin{tabular}{|c|c|c|c|c|c|c|}
\hline Entries & $\begin{array}{c}\text { No. of } \\
\text { branches } \\
\text { Iplant }\end{array}$ & $\begin{array}{c}\text { No. of } \\
\text { leaves } \\
\text { /plant }\end{array}$ & $\begin{array}{c}\text { Early } \\
\text { yield } \\
\text { (ton/fed.) }\end{array}$ & $\begin{array}{c}\text { Total } \\
\text { yield } \\
\text { (ton/fed.) }\end{array}$ & $\begin{array}{c}\text { Av. fruit } \\
\text { weight (g) }\end{array}$ & $\begin{array}{c}\text { Fruit } \\
\text { firmness } \\
\text { (g/cm })^{2}\end{array}$ \\
\hline parents & & & & & & \\
MON-5 & 5.38 & 61.61 & 6.327 & 18.147 & 170.42 & 523.33 \\
MON-8 & 6.67 & 70.83 & 5.260 & 21.648 & 133.33 & 621.67 \\
MON-9 & 6.68 & 75.27 & 8.120 & 19.378 & 91.64 & 458.33 \\
MON-15 & 5.12 & 51.52 & 4.235 & 16.550 & 138.17 & 648.33 \\
Endless Summer & 4.61 & 47.58 & 2.247 & 13.250 & 131.26 & 578.33 \\
\hline Mean & 5.69 & 61.36 & 5.23 & 17.794 & 132.96 & 566.00 \\
\hline Crosses & & & & & & \\
MON-5 x MON-8 & 7.12 & 84.43 & 6.262 & 20.820 & 150.33 & 576.67 \\
MON-5 x MON-9 & 7.01 & 75.29 & 10.103 & 18.980 & 132.25 & 511.67 \\
MON-5 x MON-15 & 6.08 & 68.04 & 5.153 & 17.857 & 152.72 & 598.33 \\
MON-5 x Endless Summer & 7.05 & 72.28 & 4.837 & 15.723 & 149.18 & 568.33 \\
MON-8 x MON-9 & 8.16 & 93.02 & 7.655 & 24.827 & 116.54 & 576.67 \\
MON-8 x MON-15 & 6.64 & 61.42 & 4.862 & 19.143 & 137.12 & 631.67 \\
MON-8 x Endless Summer & 7.18 & 78.02 & 3.778 & 17.583 & 135.49 & 591.67 \\
MON-9 x MON-15 & 8.08 & 88.39 & 7.948 & 25.508 & 121.21 & 611.67 \\
MON-9 x Endless Summer & 6.05 & 62.67 & 6.238 & 16.353 & 110.46 & 511.67 \\
MON-15 xEndless Summer & 5.53 & 54.65 & 3.865 & 15.198 & 135.33 & 621.67 \\
\hline Mean & 6.89 & 73.82 & 6.07 & 19.199 & 134.06 & 580.00 \\
\hline Alissa * & 8.02 & 90.83 & 8.122 & 25.265 & 120.43 & 671.67 \\
\hline 5 \% & 0.62 & 9.28 & 0.661 & 2.520 & 10.06 & 23.14 \\
1 \% & 0.89 & 13.44 & 0.892 & 3.648 & 13.57 & 31.23 \\
\hline LSD : & & & & & \\
\hline
\end{tabular}

* Commercial F1 hybrid (control)

Generally, the obtained data showed that, the two lines MON-8 and MON-9 could be considered as the best parental lines, since they reflected the best values for four traits. Also, the hybrid MON-9 $x$ MON-15 followed by MON-8 x MON-9 are considered as the best hybrids, they recorded the best results for four and three traits, respectively. Also, the mentioned two crosses showed insignificant differences compared with the commercial $F_{1}$ hybrid Alissa (control) for the studied traits. These two lines I hybrids may be used as new local genotypes after further evaluation in different locations.

\section{B. Components of genetic variance, heritability, General and specific combining ability effects:}

The analysis of variance for combining ability (Table 2) revealed significant mean square values for general and specific combining ability effects, indicating that both additive and 
non-additive $\left(\sigma^{2} A \& \sigma^{2} D\right)$ gene action played significant role for the expression of all the studied traits, expect average fruit weight which showed insignificant SCA mean square value. However, for number of branches and leaves per plant, the variance due to specific combining ability $\left(\sigma^{2} S C A\right)$ was higher than those of general combining ability $\left(\sigma^{2} G C A\right)$ and the ratio of additive and dominance variance $\left(\sigma^{2} A / \sigma^{2} D\right)$ which also found less than one $(0.64$ and 0.88 , respectively) revealed the preponderance of non-additive genetic variance in the inheritance of these two traits. The estimated average degree of dominance also supported the predominance of nonadditive gene action, where found more than one (1.8 and 1.5, respectively) which indicating over - dominance for these traits. Also, estimates of the proportional contribution values concerning $\left(\sigma^{2} A\right.$ and $\left.\sigma^{2} D\right)$ from the total genetic variance $\left(\sigma^{2} g\right)$ which showed $\sigma^{2} A / \sigma^{2}$ g vs $\sigma^{2} D / \sigma^{2} g$ values of 39.07 vs 60.93 and 46.95 vs 53.05 for number of branches and leaves, respectively, also revealed that the large portion of the genotypic variance $\left(\sigma^{2} g\right)$ was due to non-additive effects $\left(\sigma^{2} D\right)$.

The additive $\left(\sigma^{2} A\right)$ and dominance $\left(\sigma^{2} D\right)$ variances were the most important portions of components of genetic variance as reported by Kalloo (1988). Also, the general combining ability variance $\left(\sigma^{2} G C A\right)$ considered as an indicator of additive $\left(\sigma^{2} A\right)$ genetic variance, while the specific combining ability variance $\left(\sigma^{2} S C A\right)$ reflected the dominance $\left(\sigma^{2} D\right)$ genetic ones (nonadditive). Lastly, high values for broad since heritability $\left(\mathrm{H}^{2}{ }_{\mathrm{BS}}\right)$ for number of branches and leaves $(0.86$ and 0.81 , respectively), while low values of narrow since heritability $\left(\mathrm{H}^{2} \mathrm{Ns}\right)$ were found 0.34 and 0.38 , respectively, supported again the importance of non-additive effects in the two traits.

Table (2): Mean squares and components of genetic variance for some plant and fruit characteristics based on combined analysis.

\begin{tabular}{|c|c|c|c|c|c|c|}
\hline S.O.V. & $\begin{array}{c}\text { No. of } \\
\text { branches }\end{array}$ & $\begin{array}{c}\text { No. of } \\
\text { leaves }\end{array}$ & $\begin{array}{c}\text { Early } \\
\text { yield }\end{array}$ & Total yield & $\begin{array}{c}\text { Average } \\
\text { fruit } \\
\text { weight }\end{array}$ & $\begin{array}{c}\text { Fruit } \\
\text { firmness }\end{array}$ \\
\hline & \multicolumn{6}{|c|}{ Mean squares } \\
\hline GCA & $1.708^{* *}$ & $329.34^{* *}$ & $12.657^{* *}$ & $27.622^{* *}$ & $1244.8^{* *}$ & $8944.7^{* *}$ \\
\hline \multicolumn{7}{|c|}{ Components of genetic variance } \\
\hline$\sigma^{2} \mathrm{GCA}$ & $0.796^{* *}$ & $116.48^{* *}$ & $0.744^{* *}$ & $5.052^{* *}$ & $5.278^{\mathrm{NS}}$ & $369.4^{* *}$ \\
\hline$\sigma^{2} \mathrm{SCA}$ & 0.234 & 44.91 & 1.801 & 3.788 & 176.11 & 1268.6 \\
$\sigma^{2} \mathrm{~A}$ & 0.730 & 101.51 & 0.692 & 3.950 & -6.787 & 305.5 \\
$\sigma^{2} \mathrm{D}$ & 0.468 & 89.82 & 3.602 & 7.576 & 352.24 & 2537.4 \\
$\sigma^{2} \mathrm{~A} / \sigma^{2} \mathrm{D}$ & 0.730 & 101.51 & 0.692 & 3.950 & -6.787 & 305.5 \\
Degree of dominance & 0.64 & 0.88 & 5.2 & 1.9 & 51.9 & 8.3 \\
$\sigma^{2} \mathrm{~A} / \sigma^{2} \mathrm{~g}$ & 39.07 & 1.5 & 0.6 & 1.02 & -0.19 & 0.49 \\
$\sigma^{2} \mathrm{D} / \sigma^{2} \mathrm{~g}$ & 60.93 & 53.05 & 83.88 & 65.72 & 98.11 & 89.25 \\
$\mathrm{H}^{2}$ BS & 0.86 & 0.81 & 0.96 & 0.77 & -1.89 & 10.75 \\
$\mathrm{H}^{2}$ NS & 0.34 & 0.38 & 0.81 & 0.51 & 0.89 & 0.94 \\
\hline
\end{tabular}

*, ** significant at 0.05 and 0.01 levels of probability, respectively 
These information regarding components of genetic variance pointed out that number of branches and leaves could be improved through heterosis breeding ( $F_{1}$ hybrids). These results are in accordance with those of Singh and Asati (2011), Masry (2014), Ramana et al. (2017) and Babu et al. (2018) for number of branches; Kansouh and Zakher (2011), Aminu and Mala (2015) for number of leaves.

Regarding early and total yield, average fruit weight and fruit firmness, the larger $\sigma^{2} A$ values compared with $\sigma^{2} D$ ones which were : 3.602 vs $\mathbf{0 . 6 9 2}$, for early yield ; 7.576 vs 3.950 , for total yield; 352.24 vs -6.787 , for average fruit weight and 2537.4 vs 305.5 for fruit firmness which reflected $\sigma^{2} A / \sigma^{2} D$ ratios more than one, indicating that, the additive gene action was predominance and play the main role in the inheritance of these traits. Also, estimates of the proportional contribution values concerning $\sigma^{2} A$ and $\sigma^{2} D$ from total genetic variance $\left(\sigma^{2} g\right)$ which showed $\sigma^{2} A / \sigma^{2}$ g vs $\sigma^{2} D / \sigma^{2} g$ values of , 83.88 vs 16.12 , for early yield ; 65.72 vs 34.72 , for total yield ; 98.11 vs $-\mathbf{1 . 8 9}$, for average fruit weight and 89.25 vs $\mathbf{1 0 . 7 5}$ for fruit firmness also indicated that the large portion of the genotypic variance $\left(\sigma^{2} g\right)$ was due to additive effect $\left(\sigma^{2} A\right)$. Likewise, high heritability values were obtained for these traits, since heritability in broad since $\left(\mathrm{H}^{2}{ }_{\mathrm{BS}}\right)$ ranged from 0.77 (total yield) to 0.96 (early yield) and ranged from 0.51 (total yield) to 0.89 (average fruit weight), regarding narrow since heritability $\left(\mathrm{H}^{2} \mathrm{Ns}\right)$. Generally, these informations regarding components of genetic variance points out that early and total yield, average fruit weight and fruit firmness traits could be improved through selecting promising lines from superior hybrids, since the additive genetic variance, which are fixable (heritable) was prevalence and play the main role in the inheritance of these four traits. Several previous studies in tomato also reported the significant of additive and non-additive genetic variances with predominance of additive gene action in the inheritance of the studied same traits. Among those were Mahmoud and ELEslamboly (2014) and Aboshma et al. (2015) for early yield; Farzane et al. (2012) and Mahmoud and EL-Eslamboly (2014) for total yield; Kansouh (2013a) and Savale et al. (2017) for average fruit weight; Muttappanavar et. al. (2014) and AL-Daej (2018) for fruit firmness.

The estimates of general combining ability (GCA) effect of the parents for different characters are presented in Table (3). The good combiner parents for the studied traits were, MON-8 and MON9 for number of branches, leaves and total yield; MON-5 and MON-9 for early yield; MON-5 and MON-15 for average fruit weight; MON-8 and MON-15 for fruit firmness, since they showed significant positive GCA values. The line MON-8 and MON-9 were found to be the most desirable, where they possess dominant genes for four traits. These two lines could be used effectively in breeding for yield and other traits by hybrid breeding programs for the accumulation of favorable genes. Then, these traits could be improved by selection among the segregating generations from the superior hybrids, since high GCA effect is related additive and additive $x$ additive interaction and represents the fixable components of genetic variance (Mondal et al. 2009; Kansouh and Zakher, 2011 and Kansouh 2013a).

For specific combining ability (SCA) effects, data are presented in Table (4). The cross MON-9 X MON-15 could be considered the best combination, since it recorded the highest significant positive SCA values for all studied traits except average fruit weight, followed by the $F_{1}$ 
combination MON-8 X MON-9 which showed good SCA effects for four traits. These two crosses involved the line MON-9 as one parent, which previously showed significant positive GCA effects for four traits and considered good combiner parent.

Table (3): General combining ability effects (GCA) of the parental Genotypes for some plant and fruit characteristics based on combined analysis.

\begin{tabular}{|c|c|c|c|c|c|c|}
\hline Genotypes & $\begin{array}{c}\text { No. of } \\
\text { branches }\end{array}$ & $\begin{array}{l}\text { No. of } \\
\text { leaves }\end{array}$ & Early yield & Total yield & $\begin{array}{c}\text { Average } \\
\text { Fruit weight }\end{array}$ & $\begin{array}{c}\text { Fruit } \\
\text { Firmness }\end{array}$ \\
\hline MON-5 & $-0.133 \mathrm{M}$ & 0752M & $0.604^{* \star H}$ & $-0.387 \mathrm{M}$ & $17.593^{* *} \mathrm{H}$ & $-21.476^{* * \mathrm{~L}}$ \\
\hline MON-8 & $0.499 * * H$ & 8.220 ** $\mathrm{H}$ & $-0.224^{\star *} \mathrm{~L}$ & $1.898^{\star \star *} H$ & $0.567 \mathrm{M}$ & $24.000^{* *} \mathrm{H}$ \\
\hline MON-9 & $0.531^{* *} \mathrm{H}$ & $7.414^{\star *} \mathrm{H}$ & $1.918^{* *} \mathrm{H}$ & $1.720^{\star \star *} \mathrm{H}$ & $-19.778^{\star \star} \mathrm{L}$ & $-46.238^{\star *} \mathrm{~L}$ \\
\hline MON-15 & $-0.339 * * L$ & $-6.067^{* * \mathrm{~L}}$ & $-0.637^{* * \mathrm{~L}}$ & $-0.226 \mathrm{M}$ & $2.932^{* \star H}$ & $44.000^{* *} H$ \\
\hline Endless Summer & $-0.559 * * \mathrm{~L}$ & $-7.892^{* *} \mathrm{~L}$ & $-1.649 * * \mathrm{~L}$ & $-3.004^{* * \mathrm{~L}}$ & $-1.315 M$ & $-0.286 \mathrm{M}$ \\
\hline L.S.D. 5\% & 0.146 & 2.224 & 0.158 & 0.602 & 1.992 & 5.534 \\
\hline $1 \%$ & 0.212 & 3.226 & 0.213 & 0.872 & 2.885 & 7.466 \\
\hline $\operatorname{var}(g i-g j) 5 \%$ & 0.233 & 3.517 & 0.207 & 0.952 & 3.151 & 8.749 \\
\hline $1 \%$ & 0.337 & 5.101 & 0.301 & 1.378 & 4.562 & 11.804 \\
\hline
\end{tabular}

*, ** significant at 0.05 and 0.01 levels of probability, respectively.

$\mathrm{H}=$ Significant positive values $=$ High GCA effects

$M=$ Insignificant values = Medium GCA effects

$L=$ Significant negative values $=$ low $G C A$ effects

Table (4): Specific combining ability (SCA) effects of the $F_{1}$ crosses for some plant and fruit characteristics based on combined analysis.

\begin{tabular}{|c|c|c|c|c|c|c|}
\hline Crosses & $\begin{array}{c}\text { No. of } \\
\text { branches }\end{array}$ & $\begin{array}{c}\text { No. of } \\
\text { leaves }\end{array}$ & $\begin{array}{c}\text { Early } \\
\text { yield }\end{array}$ & $\begin{array}{c}\text { Total } \\
\text { yield }\end{array}$ & $\begin{array}{c}\text { Average } \\
\text { fruit } \\
\text { weight }\end{array}$ & $\begin{array}{c}\text { Fruit } \\
\text { Firmness }\end{array}$ \\
\hline MON-5 x MON-8 & 0.265 & $8.220^{*}$ & 0.101 & 0.579 & -1.523 & -1.190 \\
MON-5 x MON-9 & 0.121 & -2.541 & 1.785 & -1.083 & 0.738 & 4.048 \\
MON-5 x MON-15 & 0.061 & 3.686 & -0.610 & -0.261 & -1.505 & 0.476 \\
MON-5 x Endless Summer & $1.247^{* *}$ & $9.752^{* *}$ & 0.086 & 0.384 & -0.792 & $14.761^{*}$ \\
MON-8 x MON-9 & $0.638^{* *}$ & $10.147^{* *}$ & 0.184 & $2.478^{\star *}$ & 2.055 & $23.571^{* *}$ \\
MON-8 x MON-15 & -0.015 & $-7.971^{*}$ & -0.054 & -1.260 & -0.079 & -11.667 \\
MON-8 x Endless Summer & $0.751^{* *}$ & $10.447^{* *}$ & -0.125 & -0.041 & 2.541 & -7.381 \\
MON-9 x MON-15 & $1.396^{* *}$ & $17.371^{\star *}$ & $0.874^{\star *}$ & $5.283^{* *}$ & 4.356 & $38.571^{* *}$ \\
MON-9 x Endless Summer & $-0.461^{*}$ & $-6.521^{*}$ & 0.176 & -1.093 & -2.147 & $-17.143^{*}$ \\
MON-15 x Endless Summer & -0.063 & -1.063 & 0.358 & -0.303 & 0.019 & 2.619 \\
\hline L.S.D. 5\% & 0.382 & 5.745 & 0.407 & 1.554 & 5.147 & 14.287 \\
L.S.D. 1\% & 0.555 & 8.333 & 0.550 & 2.251 & 7.452 & 19.275 \\
\hline
\end{tabular}

*, ** significant at 0.05 and 0.01 levels of probability, respectively 
Generally, the cross MON-9 X MON-15, which considered the best combination, involved parents with high $x$ low and high $x$ medium GCA effects. Also, most of the significant SCA crosses mainly involved high $x$ low GCA effects. Therefore, such crosses can be used to isolate desirable segregates, as well as, in hybrid breeding for the respective characters. In this respect, since the SCA effects are considered as indicator for heterosis effects, the high amount of heterosis could be expected for number of branches and leaves which showed significant positive SCA values for four and five crosses among ten studied ones. While, low amount of heterosis could be expected for average fruit weight, since no significant SCA values were observed. This- observations was agree with the estimated degree of dominance value (Table 2) which were more than one (1.8 and 1.5) for number of branches and leaves (over-dominance), while it was $(-0.19)$ for average fruit weight which confirmed the low amount of heterosis for this trait. Then, the heterosis breeding could be used as effective method for breeding to number of branches and leaves, while selection method could be used for average fruit weight. These results are in agreement with those of Singh et al. (2010) and Kansouh (2013a).

\section{Average degree of heterosis (ADH\%) :}

For number of branches per plant (Table 5), all $F_{1}$ crosses, except MON-9 $x$ Endless Summer, showed relative heterosis, since they recorded significant ADH\% values based on mid-parents (MP), reflecting dominance towards the high number of branches. The estimated $A D H \%$ values in relation to the better parent (BPH) for these crosses showed over-dominance for four ones, where they recorded significant positive BPH\% values ranged from $13.01 \%$ (cross MON-5 $x$ MON-15) to $31.04 \%$ (cross MON-5 X Endless Summer). Complete dominance for the high branch number was detected in the remaining five crosses, since they showed insignificant $\mathrm{BPH} \%$ values. Relative to the commercial hybrid $(\mathrm{CH})$ as standard hererosis (SH \%) the two crosses MON-8 X MON-9 and MON-9 X MON-15 showed insignificant SH\% values. According to the obtaind data for this trait, the non-additive was predominance and played the main role in the inheritance of number of branches par plant, since dominance type (Table 5) reflected complete and over dominance in nine crosses.

Regarding number of leaves per plant, obtained date (Table 5) showed the same trend, since most studied crosses (six from ten ones) showed dominance towards the high number of leaves, since they recorded significant positive MPH \% values. Among of them, four crosses showed over-dominance, since recorded significant positive BPH $\%$ values (heterobeltiosis), while complete dominance was detected in two ones, since they reflected insignificant BPH \% values. However, four crosses showed no-dominance for the trait since they recorded insignificant MPH \% values. According to dominance type this trait was under additive and non-additive gene action with preponderance of nonadditive effects, since the distribution of the crosses were four ones showed nodominance (additive) while six crosses revealed complete-and over-dominance (non-additive). The obtained data supported that of combining ability (Table 2), which showed significant role regarding additive and non-additive gene action for the expression of both number of branches and leaves per plant with the prevalence of non-additive effects. these results, regarding average degree of heterosis, are in accordance with those of Tiwari and Lal (2004), Yadav et al. 
(2013) and Sahu et al. (2016), for number of branches; Kansouh and Masoud (2007) and Kansouh (2013b) for number of leaves who found heterosis for number of branches and leaves relative to the mid- and better- parents in tomato .

Table (5): Average degree of heterosis (ADH\%) based on mid-parents (MP), better parent (BP), commercial hybrid (CH), and dominance type for number of branches, leaves and early yield in the studied crosses based on combined analysis.

\begin{tabular}{|c|c|c|c|c|}
\hline \multirow{2}{*}{ Crosses } & \multicolumn{3}{|c|}{ ADH \% } & \multirow[t]{2}{*}{ Dominance type } \\
\hline & MP & BP & $\mathrm{CH}$ & \\
\hline \multicolumn{5}{|c|}{ plant/ No. of branches } \\
\hline MON-5 x MON-8 & $18.17^{* *}$ & 6.75 & $-11.22^{\star *}$ & Complete dominance \\
\hline MON-5 x MON-9 & $16.25^{\star *}$ & 4.94 & $-12.59^{\star *}$ & Complete dominance \\
\hline MON-5 x MON-15 & $15.81^{* *}$ & $13.01^{*}$ & $-24.19^{\star *}$ & Over dominance \\
\hline MON-5 x Endless Summer & $41.14^{* *}$ & $31.04^{* \star}$ & $-12.09^{* *}$ & Over dominance \\
\hline MON-8 x MON-9 & $22.25^{\star *}$ & $22.16^{* \star}$ & 1.76 & Over dominance \\
\hline MON-8 x MON-15 & $12.64^{\star *}$ & -0.45 & $-17.21^{\star *}$ & Complete dominance \\
\hline MON-8 x Endless Summer & $27.30^{* *}$ & 7.67 & $-10.47^{* *}$ & Complete dominance \\
\hline MON-9 x MON-15 & $36.95^{* *}$ & 20.96 ** & 0.75 & Over dominance \\
\hline MON-9 x Endless Summer & 7.17 & & $-24.56^{* *}$ & No-dominance \\
\hline MON-15 xEndless Summer & $13.67^{*}$ & 8.01 & $-31.05^{* *}$ & Complete dominance \\
\hline \multicolumn{5}{|c|}{ plant/No. of leaves } \\
\hline MON-5 x MON-8 & $28.10^{* *}$ & $19.76^{* \star}$ & -6.60 & Over dominance \\
\hline MON-5 x MON-9 & 10.01 & & $-17.10^{\star *}$ & No-dominance \\
\hline MON-5 x MON-15 & 20.29* & 10.43 & $-25.09 * *$ & Complete dominance \\
\hline MON-5 x Endless Summer & $32.39^{* *}$ & $17.32^{*}$ & $-20.42^{\star *}$ & Over dominance \\
\hline MON-8 x MON-9 & $27.34^{\star *}$ & $23.58^{* \star}$ & 2.41 & Over dominance \\
\hline MON-8 x MON-15 & 0.40 & & $-32.37^{* *}$ & No-dominance \\
\hline MON-8 x Endless Summer & $31.78^{* *}$ & 10.15 & $-14.10^{*}$ & Complete dominance \\
\hline MON-9 x MON-15 & $39.43^{* *}$ & $17.43^{\star *}$ & -2.68 & Over dominance \\
\hline MON-9 x Endless Summer & 2.03 & & $-31.00^{* *}$ & No-dominance \\
\hline MON-15 xEndless Summer & 10.29 & & $-39.83^{\star *}$ & No-dominance \\
\hline \multicolumn{5}{|c|}{ plant/Early Yield } \\
\hline MON-5 x MON-8 & 8.09 & & $-22.90^{* *}$ & No-dominance \\
\hline MON-5 x MON-9 & $39.86^{* *}$ & $24.42^{* \star}$ & $24.39^{* *}$ & Over dominance \\
\hline MON-5 x MON-15 & -2.42 & & $-36.56^{* *}$ & No-dominance \\
\hline MON-5 x Endless Summer & 12.82 & & $-40.45^{\star *}$ & No-dominance \\
\hline MON-8 x MON-9 & $14.42^{* *}$ & -5.73 & -5.75 & Complete dominance \\
\hline MON-8 x MON-15 & 2.41 & & $-40.14^{\star \star}$ & No-dominance \\
\hline MON-8 x Endless Summer & 0.65 & & $-53.48^{* *}$ & No-dominance \\
\hline MON-9 x MON-15 & $28.66^{* *}$ & -2.12 & -2.14 & Complete dominance \\
\hline MON-9 x Endless Summer & $20.34^{* *}$ & $-23.17 * *$ & $-23.19^{\star *}$ & Partial dominance \\
\hline MON-15 xEndless Summer & $19.25^{*}$ & -8.73 & $-52.41 * \star$ & Complete dominance \\
\hline
\end{tabular}

*, ** significant at 0.05 and 0.01 levels of probability, respectively 
For early yield, data in Table 5 illustrated that, five $F_{1}$ 's showed nodominance (additive), since they recorded insignificant MPH \% values. While, the remaining five hybrids reflected different degrees of dominance (partial, compete and over) towards the high early yield parents, since they showed significant positive MPH \% values. Among of them, the cross MON-9 $x$ Endless Summer showed partial dominance (additive and non-additive), since it recorded significant positive and negative $\mathrm{MPH} \%$ and $\mathrm{BPH} \%$ values, respectively (20.34 and $-23.17 \%)$. Other three crosses revealed complete dominance (non-additive) towards the high early yield, while, hybrid vigour (heterobeltiosis) was detected in the cross MON-5 x MON-9, with significant positive BPH\% values (24.42 \%), suggested non-additive effects . Also, the two crosses, MON-8 x MON-9 and MON-9 $x$ MON-15 showed insignificant heterosis values ( -5.73 and $-2.12 \%$, respectively) relative to the commercial hybrid Alissa $F_{1}$ (control).

With regard to total yield eight crosses showed insignificant MPH\% values suggesting no-dominance (additive gene effects) for the trait (Table 6). Meanwhile, two crosses, i.e., MON-8 XXMON-9 and MON-9 x MON-15 revealed over-dominance (heterobeltiosis) for the high total yield, suggesting non-additive gene effects, since they recorded significant positive $\mathrm{MPH} \%$ and $\mathrm{BPH} \%$ values $(21.03,41.99 \%$ as $\mathrm{MPH} \%$ and $14.68,31.63 \%$ as $\mathrm{BPH} \%$, respectively). In this respect, the mentioned two crosses showed the same total yield compared to the Alissa $F_{1}$ hybrid (control), with insignificant $\mathrm{SH} \%$ values $(-1.73$ and $0.96 \%)$. The obtained results are in agreement with those of Khalil (2009), Kansouh and Masoud (2007), Kansouh (2013b) Sahu et al. (2016), Kumar et al. (2017) and Jaiprakash Narayan et al. (2018) who found heterosis, MPH\% (relative heterosis) and BPH\% (heterobeltiosis) for early and total yield in some $\mathrm{F} 1$ tomato hybrids.

Regarding average fruit weight (Table 6), all the studied crosses showed nodominance for this trait, since they gave insignificant $\mathrm{MPH} \%$ values suggesting that weight of fruit in these materials was mostly governed by additive gene effect. However, of the tested ten crosses, three ones produced average fruit weight similar to those of the commercial hybrid Alissa $\mathbf{F}_{\mathbf{1}}$. Insignificant $\mathrm{CH} \%$ values were obtained. Likewise, no hybrid vigour (over-dominance) or standard heterosis (SH\%) were obtained for fruit firmness trait, since most tested crosses (seven from ten studied) showed insignificant MPH\% values, suggesting no-dominance (additive gene effects) for this trait. From the remaining three crosses, the combination MON-5 $\times$ MON-9 reflected complete dominance for the firmest fruit, with significant positive $\mathrm{MPH} \%$ value $(4.25 \%)$ and insignificant BPH\% value ($2.23 \%)$. Respecting the order, partial dominance toward the firmest fruit was detected in the two crosses MON-8 $x$ MON-9 and MON-9 $x$ MON-15, since they recorded significant positive MPH\% values (6.79 and $10.54 \%$ ) while showed significant negative $\mathrm{BPH} \%$ values (-7.24 and $-5.65 \%$, respectively). Similar results also were reported by Sekhar et al. (2010) and Kansouh (2013b) who reported that heterosis over the better parent for average fruit weight and fruit firmness was absent and most crosses studied showed values intermediate between their parents, while the presence of some heterosis in some crosses was due to the partial dominance. 
Table (6): Average degree of heterosis (ADH\%) based on mid-parents (MP), better parent (BP), commercial hybrid (CH), and dominance type for total yield, average fruit weight and fruit firmness in the studied crosses based on combined analysis.

\begin{tabular}{|c|c|c|c|c|}
\hline \multirow{2}{*}{ Crosses } & \multicolumn{3}{|c|}{ ADH \% } & \multirow[t]{2}{*}{ Dominance type } \\
\hline & MP & BP & $\mathrm{CH}$ & \\
\hline \multicolumn{5}{|c|}{ Total yield/plant } \\
\hline MON-5 x MON-8 & 4.64 & & $-17.59 * *$ & No-dominance \\
\hline MON-5 x MON-9 & 1.16 & & $-24.87^{\star *}$ & No-dominance \\
\hline MON-5 x MON-15 & 2.93 & & $-29.32^{\star *}$ & No-dominance \\
\hline MON-5 x Endless Summer & 0.16 & & $-37.77^{* *}$ & No-dominance \\
\hline MON-8 x MON-9 & $21.03^{* *}$ & $14.68^{* *}$ & -1.73 & Over dominance \\
\hline MON-8 x MON-15 & 0.23 & & $-24.23^{* *}$ & No-dominance \\
\hline MON-8 x Endless Summer & 0.77 & & $-30.41^{* *}$ & No-dominance \\
\hline MON-9 x MON-15 & $41.99^{* *}$ & $31.63^{\star *}$ & 0.96 & Over dominance \\
\hline MON-9 x Endless Summer & 0.24 & & $-35.27^{* *}$ & No-dominance \\
\hline MON-15 x Endless Summer & 2.00 & & $-39.85^{\star *}$ & No-dominance \\
\hline \multicolumn{5}{|c|}{ Average fruit weight } \\
\hline MON-5 x MON-8 & -1.01 & & $24.82^{\star *}$ & No-dominance \\
\hline MON-5 x MON-9 & 0.93 & & $9.81^{* *}$ & No-dominance \\
\hline MON-5 x MON-15 & -1.02 & & $26.81^{\star *}$ & No-dominance \\
\hline MON-5 x Endless Summer & -1.01 & & $23.87^{* *}$ & No-dominance \\
\hline MON-8 x MON-9 & 3.60 & & -3.23 & No-dominance \\
\hline MON-8 x MON-15 & 1.01 & & $13.86^{* *}$ & No-dominance \\
\hline MON-8 x Endless Summer & 2.42 & & $12.51^{\star *}$ & No-dominance \\
\hline MON-9 x MON-15 & 5.49 & & 0.65 & No-dominance \\
\hline MON-9 x Endless Summer & -0.89 & & -8.28 & No-dominance \\
\hline MON-15 x Endless Summer & 0.46 & & $12.37^{* *}$ & No-dominance \\
\hline \multicolumn{5}{|c|}{ Fruit firmness } \\
\hline MON-5 x MON-8 & 0.73 & & $-14.14^{\star *}$ & No-dominance \\
\hline MON-5 x MON-9 & $4.25^{*}$ & -2.23 & $-23.82^{* *}$ & Complete dominance \\
\hline MON-5 x MON-15 & 2.13 & & $-10.92^{* *}$ & No-dominance \\
\hline MON-5 x Endless Summer & 3.18 & & $-15.39 * *$ & No-dominance \\
\hline MON-8 x MON-9 & $6.79 * *$ & $-7.24^{\star *}$ & $-14.14^{\star *}$ & Partial dominance \\
\hline MON-8 x MON-15 & -0.52 & & $-5.96^{* *}$ & No-dominance \\
\hline MON-8 x Endless Summer & -1.39 & & $-11.92^{\star *}$ & No-dominance \\
\hline MON-9 x MON-15 & $10.54^{* *}$ & $-5.65^{\star *}$ & $-8.93^{\star *}$ & Partial dominance \\
\hline MON-9 x Endless Summer & -1.28 & & $-23.82^{\star *}$ & No-dominance \\
\hline MON-15 x Endless Summer & 1.36 & & $-7.44^{\star *}$ & No-dominance \\
\hline
\end{tabular}

*, ** significant at 0.05 and 0.01 levels of probability, respectively. 
Regarding dominance type for early and total yield, average fruit weight and fruit firmness (Table 5 and 6), the distribution of the crosses showed that, the large number of the tested crosses showed no-dominance (additive gene effects), while partial dominance (additive and non-additive effects ) was detected in some crosses and little few number showed complete - and over dominance (non-additive effects), suggesting that , the additive gene action was prevalence and play the main role in the inheritance of these four traits. This opinion was supported the combining ability estimates (Table 2) which suggested the prevalence of additive genetic variance for these four traits. Therefore, these four characters could be improved by varietal breeding through selection methods, while for number of branches and leaves, since non-additive genetic variance was preponderance, these two traits could be improved by F1 hybrid (heterosis) breeding program.

These results regarding average degree of heterosis and genetic variance effects (additive and non-additive) were agreement those of Goyal and Kumar (1988), Mohanty and Mishra (1999) and Kansouh (2014) who revealed that, the high degree of heterosis (complete and over-dominance) reflected the presence of high non-additive effects, meanwhile absence of heterosis (no-dominance) could be considered as a criterion of additive effects. Therefore, heterosis study of the hybrids may be considered as one of the modern practices to determine additive and non-additive genetic variances as the combining ability method.

\section{CONCLUSION}

Analysis of variance showed that additive genetic variance was more important and play the main role in the inheritance of early and total yield, average fruit weight and fruit firmness and varietal breeding through selection methods may be more effective to improved these traits in tomato. While, number of branches and leaves traits could be improved by heterosis breeding, since the non-additive genetic variance play the main role in the inheritance of these traits. The hybrid breeding method based on standard heterosis can be used efficiently to improve tomato yield and quality in Egypt by developing superior local hybrids.

\section{REFERENCES}

Aboshama, H. M., K. F. M. Salem, Horeya M. F. Hassan and M. H. Tahoun (2015). Estimating heterois and combining ability for in vivo and in vitro traits using diallel cross on tomato (Solanum lycopersicum L.). Menoufia J. Agri. Res. 40 (2): 757-770 .

AL-Daej, M. I. (2018). Line $X$ tester analysis of heterosis and Combining ability in tomato (Lycopersicon esculentum Mill.). Pakestan J. Biol. Sci., 21(5) : 224-231.

Aminu, D. and K. K. Mala (2015). Combining ability estimates for Tomato (Solanum lycopersicum L.) Resistance to nematode (Meloidogyne spp.) in the Sudan Savannah of Nigeria. J. Agri. Econ. Environ And Social Sci., 1 (1): 40 - 45.

Babu, M. R., R. V. S. K. Reddy, K. R. Reddy, A. S. Rani and P. Saidaiah (2018). Genetic improvement for yield, Quality and leaf curl virus resistance in tomato (Solanum lycopersicum L.). J. pharmacognosy and Phytochemistry, SPI : 1048 - 1055.

Enang, E. M., A. M. Kadams, S. Y. Simon and S. J. Louis (2015). Heterosis and general combining ability study on heat tolerant tomato (Lycopersicon esculentum Mill.). Inter. J. Hort., 5 (17): $1-7$. 
Farzane, A., H. Nemati, H. Arouiee, A. M. Kakhki and N. Vahdati (2012). The estimate of combining ability and hetrosis for yield and yield components in tomato (Lycopersicon esculentum Mill.). J. Biol. Environ. Sci., 6 (17) : 129 - 134.

Goyal, S. N. and S. Kumar (1988). Heterosis in relation to general and specific combining ability in sesame. Indian J. Hort. 56 (2): 173 - 178.

Griffing, B. (1956). Concept of general and specific combining Ability in relation to diallel crossing system. Aust. J. Biol. Sci., 9: 463 - 493.

Jaiprakash Narayan, R. P., S. B. Mallesh, M. G. Patil and M. Dhotre (2018). Heterosis and combining ability for tomato leaf curl virus (ToLCV) and Bacterial wilt disease in tomato (Solanum lycopersicum L.). Electronic J. Pl. Breed., 9 (1):73 - 81.

Kalloo, (1988). Vegetable breeding. CRC Press Inc., 200 Corporate Blvd., NW. Boca Raton, Florida, Vol. 1, PP. 61.

Kansouh, A. M. (2014). Association of hybrid performance, heterosis and dominance types in pepper (Capsicum annuum, L.). J. Pl. Product., Mansoura Univ., 5 (8): 1471 - 1490.

Kansouh, A. M. (2013a). Genetic analysis for some tomato traits. Egypt. J. of Appl. Sci. , 28 (11) : 732 - 743.

Kansouh, A. M. (2013b). Developing new tomato hybrids at middle Delta regions of Egypt. Egypt. J. of Appl. Sci., 28 (11): 744 - 758.

Kansouh, A. M. and A. G. Zakher (2011). Gene action and Combining ability in tomato (Lycopersicon esculentum Mill.) by line $x$ tester analysis. J. Pl. Prod., Mansoura

$$
\text { Univ., } 2 \text { (2): } 213 \text { - } 227 .
$$

Kansouh, A. M. and A. M. Masoud (2007). Manifestation of heterosis in tomato (Lycopersicon esculentum Mill.) by Line $x$ tester analysis. Alex. J. of Agric. Res. 52(1): 75-90.
Kearsey, M. J. and H. S. Pooni (1996). The genetical analysis of Quantitative traits. Published by Chapman \& Hall, 2-6 Boundary Row, London, SE1 8 HN, UK., PP. 50.

Khalil, Mona R. (2009). Studies on the inheritance and types of Gene action for some tomato characters. Ph. D. Thesis, Fac. Agric., Minufiya Univ., Egypt, P. 187.

Kumar, M. S., A. K. Pal, B. Rajasekhar Reddy, Anil K. Singh and Anand K. Singh (2017). Heterosis and inbreeding depression studies for yield and yield related traits in tomato (Solanum lycopericum L.). Int. J. Curr. Microbiol. App. Sci, 6 (11): 1240 1247.

Kumari, W. and J. P. Srivastava (2017). Combining ability of quality traits and yield in tomato (Solanum Iycopersicon Mill. ). Vegetable Science. 34(1): 99 100.

Mahmoud, A. M. A. and A. A. S. A. ELEslamboly (2014). Genetic analysis to find suitable parents for development cherry tomato hybrids under green house conditions. Egypt. J. Plant Breed., 19 (1) : 55 - 70.

Masry, A. I. A. M. (2014). Heterosis and gene action in tomato Crosses under tomato yellow leaf curly virus infection. Ph. D. Thesis, Fac. Agric., Kafr-Elsheikh Univ., Egypt.

Mather, K. and J. L. Jinks (1971). Biometrical genetics $\left(2^{\text {nd }} E \quad\right.$ d.). Chapman and Hall, Ltd, London, P. 382.

Mohanty, B. K. and R. S. Mishra (1999). Studies on heterosis for yield and yield attributes in pumpkin (Cucurbita moscata Duch. Ex. Poir.). Indian. J. Hort., 56 (2): 173 - 178.

Mondal, C., S. Sarkar and P. Hazara (2009). Line $x$ tester analysis of combining ability in tomato (Lycopersicon esculentum Mill.). J. of crop and Weed, 5 (1): 53 - 57. 
Muttappanavar, R. D., A. T. Sadashiva, R. C. Vijendrakumar, B. N. Roopa and P. T. Vasantha (2014). Combining ability analysis of growth, yield and quality traits in cherry tomato (Solanum lycopersicum var. cersiforme). Molecular plant Breeding, 5 (4) : 592 600.

Rakesh, G. (2016). Genetic studies for yield and quality traits in tomato (Solanum lycopersicum L.). Ph. D. Thesis, Department of vegetable science, Dean, College of Horticulture, India.

Ramadan, W. A., S. T. EL-Afifi and P. A. Abdelmalek (2014). Combining ability analysis for yield and its attributing traits in tomato (Lycopersicon esculentum Mill.). J. PI. produc., Mansoura Univ., 5 (5): 869 - 883.

Ramana, V., D. Srihari, R.V.S.K. Reddy, M. Sujatha and M. H. V. Bhave (2017). Combining ability studies in tomato (Solanum lycopersicum L.) for yield attributes, Yield and quality. $J$. of pharmacognosy and Phytochemistry; SPI : 933 - 937.

Sahu, M., K. K. Sahu, A. Tirkey, D. Upadayay and N. Mehta (2016). Heterosis and inbreeding depression for agro- morphological characters in tomato (Lycopersicon esculentum Mill). Inter. J. of Farm Sci., 6 (2): 51 64.

Savale, S. V., A. I. Patel and P. R. Sante (2017). Study of heterosis over Environments in tomato (Solanum lycopersicum L.). Inter. J. of Chemical studies, 5 (3): 284-289.

Sekhar, L., B. G. Prakash, P. M. Salimath, H. P. Cannayya, O. Sridevi and A. A. Patel (2010). Implication of heterosis and combining ability among productive single cross hybrids in tomato. Electronic J. of PI. Breed., 1 (4): 706 - 711.

Shende, V. D., S. Tania, M. Subhra and C. Arup (2012). Breeding tomato (Solanum lycopersicum L.). For higher Productivity and better processing qualities. SABRAO J. of Breed And Genet. , 44 (2): 302 - 321. Singh, A. K. and B. S. Asati (2011). Combining ability and heterosis studies in tomato under bacterial wilt Condition. Bangladesh J. Agric. Rese., 36 (2): 313 $-318$.

Singh, R. K. and B. D. Chadhary (1995). Biometrical methods in Quantitative genetic analysis. Kalyani publishers, Ludhiana, New-Delhi, India.

Singh, B., S. Kaul, D. Kumar and V. Kumar (2010). Combining Ability for yield and its contributing characters in tomato. India J. Hort., 67 (1): 50 - 55.

Tiwari, A. and G. Lal (2004). Studies on heterosis for qualitative And quantitative characters in tomato. Progressive. Hort., 36: 122 - 127.

Yadav, S. K., B. K. Singh, D. K. Baranwal and S. S. Solankey (2013). Genetic study of heterosis for yield and quality Components in tomato (Solanum lycopersicum). African J. of Agric. Res. 8 (44): 5585 - 5591. 
التحليل الوراثى وقوة الهجين لبعض الصفات الكمية فى الطماطم

منى رشدى خليل (') ، محمود إبراهيم محمود (†)

(1) قسم البساتين - كلية الزراعة - جامعة المنوفية النية

(r) قسم الإنتاج النباتي - كلية العلوم الزراعية البيئية -جامعه العريش- مصر البنة

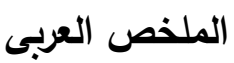

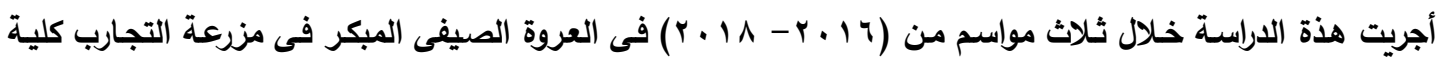

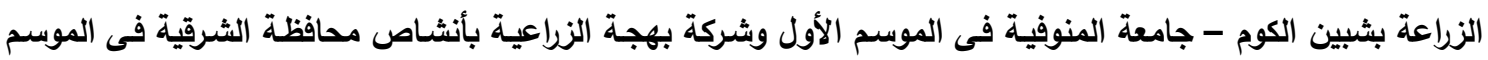

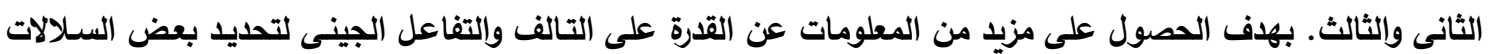

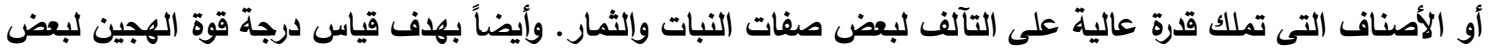

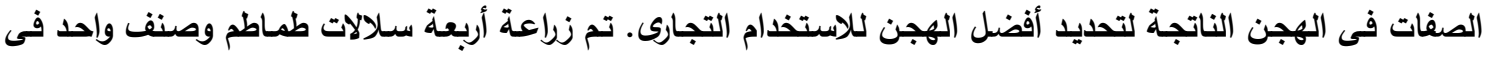

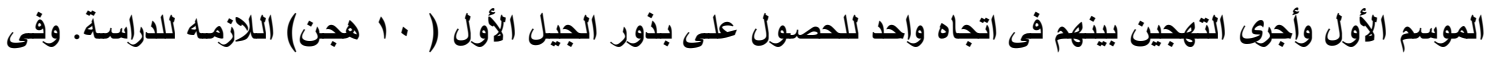

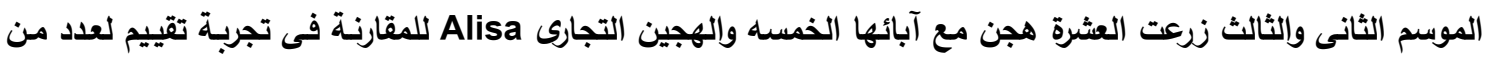

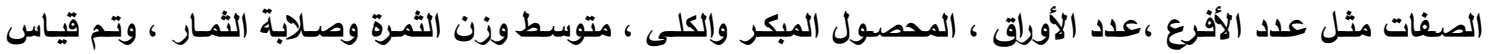

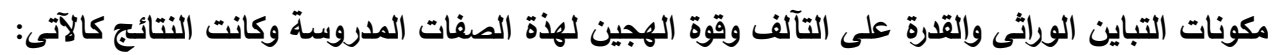

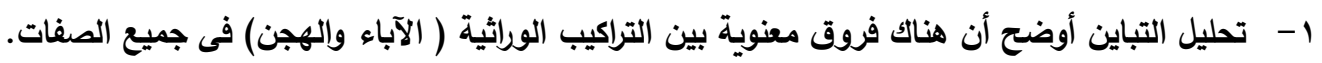

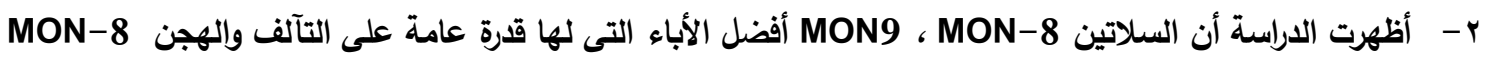
وعا الأفضل بالنسبة للقدرة الخاصة على التآلف حيث سجلت قيم موجبة

وعالية المغنوية.

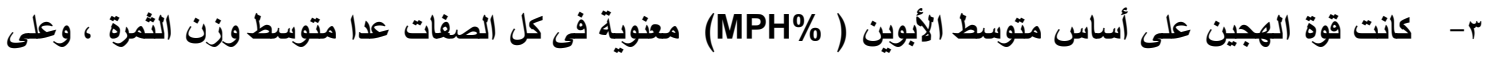

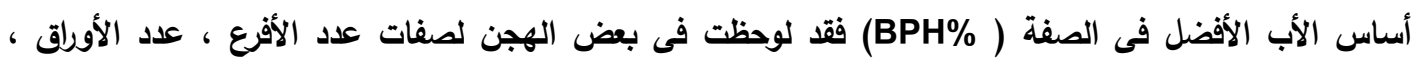

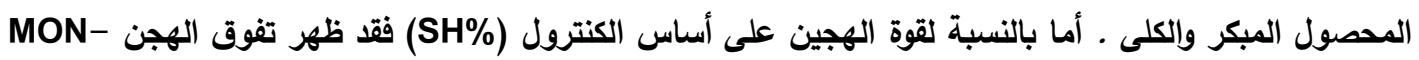
. MON-9 × MON-15، 8 × MON-9 ع - وأوضحت حسابات القدرة العامة والخاصة على التآلف أن التأثير الإضافى واللإضافى للجينات كان معنوى وهام لكل

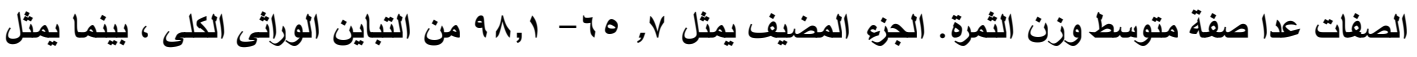

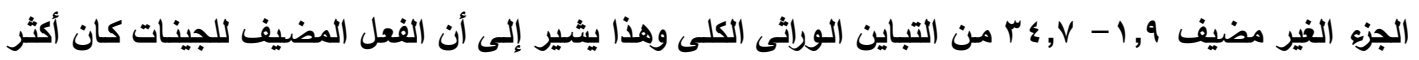

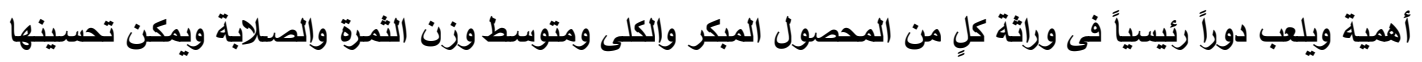

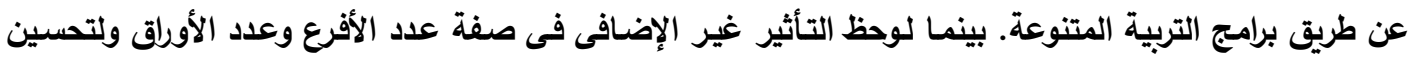
هاتين الصفتين يكون عن طريق إنتاج الهجن، أى استخام ظاهرة قوة الهجين.

أسماء السادة المحكمين

معه بحوث البساتين- مركز البحوث الزراعية - الجيزة

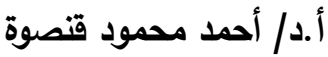

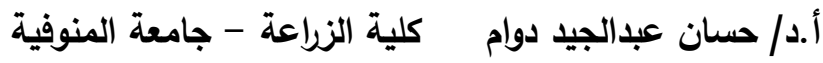


